\title{
The vaccination of man and other animals against rabies
}

\author{
JOAN CRICK \\ M.Sc. \\ Department of Biochemistry, Animal Virus Research Institute, Pirbright, Woking, Surrey
}

\begin{abstract}
Summary
Rabies vaccines and their use in man and other animals are described. Safe and reliable vaccines are available for veterinary use, but many of the problems associated with the vaccination of humans remain unsolved.
\end{abstract}

\section{Introduction}

Rabies is caused by a virus which can infect many warm-blooded animals, including man. It is transmitted from one animal to another, usually by biting, although this is not the only means by which the disease is spread. For example, airborne infection is known to occur (Constantine, 1962; Winkler, Baker \& Hoskins, 1972). Not all individuals exposed to rabies virus develop the disease and in those that do there is a considerable delay between the time of exposure and the development of the first clinical signs. However, once these do appear, death is virtually certain, although the first well-documented account of human recovery from the disease appeared recently (Hattwick et al., 1972), and there are reports in the literature of symptomless carriers and recovered or abortively infected animals (Bell, 1964; Chalmers \& Scott, 1969; Matsumoto, 1970; Hattwick et al., 1972; Afshar, Bahmanyar \& Fayaz, 1972).

The pathogenesis of rabies is still not fully understood. Viraemically distributed virus has been demonstrated in the brain (Krause, 1966) but most experimental evidence supports the view that, when infection occurs, the virus travels from its site of entry into the body along peripheral nerves to the central nervous system. The interval between exposure and the entry of the virus into the peripheral nerves has been previously estimated at not more than 3 days (Habel, 1954; Schindler, 1966). However, Baer \& Cleary (1972) have shown that, in a model system which closely resembles the human situation after exposure, the virus remains at or near its site of introduction for most of the incubation period. If indeed this is what happens in man, we can begin to understand why post-exposure vaccine therapy can work and perhaps develop more rational and less unpleasant courses of treatment than are available at the present time.
The use of rabies vaccines

Since the days of Pasteur, vaccination has played an important part in the protection of man against rabies. Nowadays, pre-exposure immunization of both domestic animals and persons at risk is widely practised, but the first vaccines were used solely for the treatment of people who had been bitten by rabid animals. These people were given daily doses of vaccine for about 2 weeks. This practice of immunization after infection, unique in preventive medicine, is still continued and each year between 500,000 and $1,500,000$ people throughout the world receive a course of treatment not very different from that used by Pasteur. The treatment is dreaded because it is often painful and there is a very real risk of postvaccinal complications, some of which are severe (Abdussalam \& Bögel, 1971). In the last 15-20 years the treatment has become even more unpleasant because of the frequent inclusion of antiserum at the beginning of the course of vaccination (see p. 556).

The value of pre-exposure immunization of animals as a means of controlling rabies was emphasized by Meyer (1954). Pasteur was fully aware of the transference of rabies from one dog to another and the danger of rabid dogs to man, but it was not until after the First World War that the first mass vaccination of dogs took place. At that time Hungary was the country in Europe most affected by rabies but, by using an inactivated nervous tissue vaccine and increasing the number of dogs vaccinated each year, and finally making vaccination compulsory in 1939, the country was virtually freed from the disease. A resurgence in Hungary after the Second World War was similarly treated, and by 1950 all the dogs in the country were vaccinated (Meyer, 1954). Dog vaccination was also used successfully for the control of the disease in Japan (Umeno \& Doi, 1921), but no carefully controlled dog experiments were made until 1945, when Johnson showed the efficacy of a single dose of vaccine as a preventive measure (Johnson, 1954). In 1951 a large-scale clinical evaluation of dog vaccination was made in St Louis, Missouri, U.S.A., where the history of epizootics had been carefully documented over 20 years. Using a phenolized 
vaccine, 58,000 dogs were vaccinated and the disease virtually disappeared within 9 months. In contrast, previous outbreaks had lasted several years and declined only slowly (Fredrickson et al., 1953).

More recently, live rabies vaccines (see below) have been used extensively for canine vaccination. For example, the Flury LEP (low egg passage) vaccine (Koprowski \& Cox, 1948) was the one generally used in the U.S.A. between 1953 and 1965, when the number of confirmed rabies cases in dogs was reduced from 5688 to 412 (Center for Disease Control, 1969 Zoonoses Surveillance, Annual Summary, Rabies-quoted by Sikes, 1971). The successful use of the same vaccine in Malaya, Israel and Rhodesia was reported in the Bulletin of the World Health Organization (1954) and in many countries the annual vaccination of dogs is now compulsory.

In many parts of the world, rabies is maintained not in the canine but in the sylvatic population. Kaplan (1969) stated that in Central and South America, for example, rabies transmitted by vampire bats is estimated to kill up to $1,000,000$ cattle each year, although there are relatively few official reports of actual cases. The annual cost of the disease to the farming industry has been calculated at \$70,000,000 (Hubbard, 1969). Until efficient methods are evolved for the destruction of the bats, vaccination of exposed animals seems the only method of limiting the disease, and experiments to decide the most effective vaccine for this purpose were described by Hubbard (1969) and Dreeson, Eubanks \& Behymer (1970).

In Europe and the U.S.A., foxes and skunks respectively are the most commonly infected animals, and in four recent papers (Schmidt \& Sikes, 1968; Baer, Abelseth \& Debbie, 1970; Black \& Lawson, 1970; Debbie, Abelseth \& Baer, 1972) the successful experimental vaccination of foxes was described. Schmidt \& Sikes (1968) immunized the animals by intramuscular inoculation of an inactivated nervous tissue vaccine, while the other workers gave the live ERA vaccine orally with the idea that this or a similar vaccine could be given to wild foxes in bait.

\section{How do rabies vaccines work?}

Although vaccinated dogs and cattle with no detectable serum neutralizing antibody remaining may still resist experimental infection (Hubbard, 1969), the level of neutralizing antibody is usually regarded as a measure of the efficacy of pre-exposure vaccination. In fact, a direct relationship between neutralizing antibody level and protection against challenge has been demonstrated in several animal species (Tierkel, 1949; Dean, 1964; Cabasso, 1966; Crick \& Brown, 1969; Turner, 1962). In the postexposure vaccination of humans the role of antibody in preventing the disease is difficult to explain unless virus does remain outside the nervous system an\& therefore accessible to antibody for a considerable. period, as is suggested by the results of Baer \& Cleary (1972). The concept of using daily doses of vaccine cannot be immunologically sound and the fact that animals may be protected after exposure by a single dose of concentrated tissue culture vaccined (Sikes et al., 1971; Wiktor, 1971; Baer \& Cleary 1972) suggests that in future protection for man mayes be conferred by a less rigorous regimen than used $\bar{E}$ nowadays.

Wiktor, Postic \& Koprowski (1972) have now found that vaccine prepared from virus grown in BHK 21 cells (Macpherson \& Stoker, 1962), then concentrated and inactivated, stimulates the pro duction of interferon in hamsters during the 24 hro following intramuscular inoculation, and Baer \& Cleary (1972) obtained a similar result in mice up to $32 \mathrm{hr}$ after inoculation. Their results led Baer \& Cleary (1972) and Wiktor et al. (1972) to suggesto that interferon may play a part in protection against $\_$ the disease if the vaccine is given at or near the time of challenge. However, Turner (1972) was unable tœo demonstrate interferon production or immediates protection against lethal challenge in rabbits, miceor hamsters after the inoculation of various andirabies vaccines, and stated that 'effective immunify' against rabies appears at present to be related soletyo to humoral antibody' (Turner, 1973).

\section{The development of rabies vaccines}

Rabies vaccines are produced in mammalian $\stackrel{\Phi}{\circ}$ nervous tissue, chick or duck embryo, and in $\vec{a} \overrightarrow{\overrightarrow{0}}$ variety of tissue culture systems. The development of 3 each will be considered separately. A number of vaccines give excellent results in animals but none? is completely satisfactory for use in man.

\section{(a) Nervous tissue vaccine}

The first experimental vaccines were made by Pasteur and his co-workers, Roux \& Chamberland, 윽 in the early 1880 's, using virus isolated from rabid dogs which they had passaged in rabbits. After 3 about fifty intracerebral passages in rabbits the virus no longer infected dogs by the subcutaneous route, although its pathogenicity for rabbits had increased. N Further passages in rabbits did not appear to alter its biological properties and the virus was now referred to as 'fixed' to distinguish it from the natural or 'street' virus present in the saliva of rabid animals.

When rabbits infected with 'fixed' virus died, the spinal cords were removed and dried over potassium? hydroxide for varying lengths of time. The dried cords were almost completely avirulent after 2 weeks. $\frac{O}{\mathbb{D}}$ A dog would be given cord dried for 14 days on the $\frac{\rho}{\Phi}$ 
first day, cord dried for 13 days on the second, and so on. At the end of two week the dog would be completely immune to intracerebral challenge with fully virulent virus (see Parish, 1965).

Pasteur's next experiments were conducted with dogs which had been bitten by a rabid animal, that is, treatment was given after exposure to the virus. The rationale of this treatment remains to be convincingly argued but was tried because of the long incubation period of the disease (a month or more in dogs). Despite this unorthodox method of prophylaxis, the experiments were successful and the dogs were protected from the disease (Parish, 1965).

In 1885, a 9-year-old boy, Joseph Meister, badly bitten by a rabid dog, became the first human to be treated with the new vaccine. He received thirteen doses of rabbit cord vaccine, the first of which had been dried for 15 days and the last for 1 day (Pasteur, 1885). Joseph Meister did not develop rabies, and in the next year about 2500 exposed persons were similarly treated, only twelve of whom died (see Turner, 1969).

Since that time "little if any improvement has been made in the preparation of rabies vaccines' (Koprowski, 1971) and Pasteur's influence on the prophylactic treatment of rabies remains. More nervous tissue vaccines are used than any other type, for they are the most potent antigens yet developed for humans and are also widely used for animal vaccines. The usual course of treatment for post-exposure immunization of humans is still fourteen, and in some cases twenty-one, daily doses of vaccine, with booster doses recommended at 10 and 21 days after the last daily dose (particularly recommended if antiserum has been given on the first day-see Habel, 1966). Although few people have actually commented on the wisdom or otherwise of so many doses of antigen so close together, inferior antibody responses were obtained in human volunteers given fewer doses more widely spaced (Atanasiu et al., 1957), and Plotkin \& Clark (1971) made the statement that 'daily stimulus is necessary'. Doubts about the effect of the treatment on the mortality rate of exposed persons were expressed by Meyer (1954) and, as pointed out by Plotkin \& Clark (1971), controlled studies on its efficacy have never been made. However, Veeraraghavan (1969) stated that in India $56 \%$ of untreated exposed subjects developed the disease, compared with only $7 \%$ of vaccinated persons. Even better results are claimed when antiserum is included in the therapy (see p. 556).

There have been many modifications of Pasteur's original method of preparing nervous tissue vaccine, including those of Fermi (1908) and Semple (1911) (see Turner, 1969). In the Fermi vaccine, virus is partially inactivated with phenol but retains a titre of about $10^{4.2} \mathrm{LD}_{50}$ per ml (Lépine, 1966). This was the vaccine used in the famous field trial in Iran when the value of anti-serum in prophylaxis was demonstrated (see p. 556). The use of this and other partially inactivated vaccines for man is now declining (Abdussalam \& Bögel, 1971; Fenje, 1971).

Semple-type vaccine, which was originally made from sheep brain, is the most widely used vaccine today for the post-exposure treatment of humans and for animal vaccination. Other animal brains are now also used for its preparation and the virus is completely inactivated with phenol, $\beta$-propiolactone (BPL) or ultraviolet light. Semple vaccine is not recommended for pre-exposure immunization of humans.

Unfortunately, prolonged therapy with nervous tissue vaccine is associated with a risk of postvaccinal reaction, because adult brain contains an encephalitogen associated with myelin. The average incidence of neural complications in people vaccinated was given by Abdussalam \& Bögel (1971) as being about $1 / 160$, with fatal termination in $1 / 11,000$. Numerous attempts have been made to remove the encephalitogen (Turner, 1969), one of the most successful of which appears to be that of Kaplan \& Turner (1968), who used the fluorocarbon, Arkton, for this purpose. Their modified Semple vaccine is now licensed for use in Britain and is at present being evaluated in a group of volunteers.

The brains of very young animals contain very small amounts of myelin and are therefore considered to be free from the paralytic factor. Fuenzalida \& Palacios (1955) showed that a vaccine of high immunogenicity could be produced easily and comparatively cheaply from the brains of suckling mice. Similar vaccines have been prepared from suckling rat brains in the U.S.S.R. (Svet-Moldavskij et al., 1965) and from suckling rabbit brains in the Netherlands (Gispen \& Saathof 1965; Gispen, Schmittmann \& Saathof, 1965). Suckling mouse brain vaccines inactivated by ultraviolet light, BPL or phenol are now the most widely used in South America for post-exposure therapy and pre-exposure immunization of persons at high risk. In addition, many thousands of doses are produced each year for use in animals. By centrifugation and chromatography of crude brain suspensions, Sikes \& Larghi (1967) obtained a 'purified' vaccine, and suckling rat brain virus separated by density gradient centrifugation has also been used for an experimental vaccine (Lavender, 1970).

However, Held \& Adaros (1971) have reported cases of neurological disease following administration of suckling mouse brain vaccine during the period 1964-1969. The neurological symptoms were quite different from those which have been seen after vaccination with mature nervous tissue vaccines. 
Most cases had a Guillain-Barré syndrome with peripheral nervous tissue involvement and there was a higher case-fatality ratio. The causative agent has not yet been identified.

\section{(b) Avian tissue vaccine}

The advantages of rabies vaccines which are free from nervous tissue are obvious, and for a number of years rabies vaccines prepared in avian tissue have been available. Two of the best known, the Flury LEP and HEP vaccines, are prepared in chick embryos and used as live vaccines. The Flury strain was originally isolated from a girl of that name, passaged in day-old chicks and then adapted to chick embryos by Koprowski \& Cox (1948). The Flury LEP (low egg passage) vaccine consists of virus at the 40th to 50th egg passage level. Although Bell (1967) has questioned the wisdom of using such a vaccine because of its known pathogenicity for certain species, e.g. cattle, cats and young puppies, it appears safe for adult dogs and has been widely used in rabies eradication campaigns (see p. 551 above; Bulletin of the World Health Organization, 1954; Cabasso, 1966). Johnson (1954), quoting experiments by Koprowski \& Black (1952), claimed that one dose of LEP vaccine gave a longer immunity in dogs than a single dose of phenolized brain vaccine. More recently, LEP vaccine has been shown to compare favourably with the newer attenuated and inactivated tissue culture vaccines and with suckling mouse brain vaccine (Sikes, 1971).

Flury HEP (high egg passage) vaccine, which consists of virus at the 180th egg passage level, is safe for puppies, cats and cattle, and Hubbard (1969) found that cattle inoculated with it were resistant to challenge 22 months later. However, dangers inherent in the use of live vaccines preclude their use in countries, such as Britain, where the disease is not endemic. The Report of the Committee of Enquiry on Rabies (Report, 1971) does 'not recommend use of a live vaccine for vaccination in this country', although the dogs to be vaccinated would in fact be those confined to quarantine kennels.

Flury HEP has also been extensively tried for the pre-exposure immunization of man, but with disappointing results (see Turner, 1969, for references). Doubts about its use were expressed by Schwab et al. (1954), and Fox et al. (1957) came to the conclusion that the virus failed to multiply in extraneural human tissues. Consequently, it is no better, and may be more dangerous, than an inactivated vaccine containing the same amount of antigen. The W.H.O. Expert Committee, in its 5th Report (W.H.O., 1966), suggested that use of both Flury vaccines should be limited to animals.

In order to obtain higher yields of virus, a fixed virus strain was grown in duck embryos and be inactivation of this material with BPL the now well $\mathbb{Q}$ known duck embryo vaccine (DEV) was first pre. pared (Peck, Powell \& Culbertson, 1956). In clinical trial conducted by Greenberg \& Childress (1960) the results suggested that antibody was proE duced more rapidly in persons receiving duck embry vaccine than in a second group receiving Semple vaccine. On the other hand, Dean \& Sherman (1962 found that the potency level of DEV is consistently lower than those of nervous tissue vaccine, but nevertheless 'satisfactory' (Habel, 1966). Gravedoubts as to the efficacy of DEV were subsequentl产 expressed by Crick \& Brown (1970a). The twe English cases of canine rabies in Camberley (Octobe 1969) and Newmarket (February 1970) provide these workers with the opportunity to examine serm from patients who received the recommende\& fourteen daily doses of duck embryo vaccine. Onl $\vec{G}$ four out of thirteen persons vaccinated with fourtee doses produced significant amounts of antibodø (Table 1). The high level of neutralizing antibody

TABLE 1. Neutralizing antibody in serum of patients receiving fourteen consecutive daily doses of rabies duck-embryo vaccine (from Crick \& Brown, 1970a)

\begin{tabular}{|c|c|c|}
\hline Patient & $\begin{array}{l}\text { Days after } \\
\text { first dose } \\
\text { of vaccine }\end{array}$ & $\begin{array}{c}\text { Neutralizing } \\
\text { activity in } \\
0.015 \mathrm{ml} 1 / 10 \text { serum } \\
\left(\log \mathrm{ID}_{50}\right)\end{array}$ \\
\hline A & $\begin{array}{r}11 \\
33 \\
110\end{array}$ & $\begin{array}{l}4 \cdot 0 \\
3 \cdot 7 \\
4 \cdot 1\end{array}$ \\
\hline B & $\begin{array}{r}10 \\
54 \\
109\end{array}$ & $\begin{array}{l}0.4 \\
0.0 \\
0.0\end{array}$ \\
\hline C & $\begin{array}{r}7 \\
29 \\
106\end{array}$ & $\begin{array}{l}0 \cdot 4 \\
2 \cdot 0 \\
1 \cdot 0\end{array}$ \\
\hline D & $\begin{array}{r}10 \\
23 \\
106\end{array}$ & $\begin{array}{l}0 \cdot 8 \\
2 \cdot 0 \\
2 \cdot 2\end{array}$ \\
\hline $\mathrm{E}$ & $\begin{array}{r}23 \\
106\end{array}$ & $\begin{array}{l}0.8 \\
0.0\end{array}$ \\
\hline $\mathbf{F}$ & 14 & $1 \cdot 8$ \\
\hline G & 27 & 1.0 \\
\hline $\mathbf{H}$ & 27 & $1 \cdot 0$ \\
\hline I & $\begin{array}{r}7 \\
21\end{array}$ & $\begin{array}{l}0.8 \\
2.0\end{array}$ \\
\hline $\mathbf{J}$ & $\begin{array}{r}7 \\
21\end{array}$ & $\begin{array}{l}0.0 \\
0.4\end{array}$ \\
\hline $\mathbf{K}$ & $\begin{array}{r}8 \\
22\end{array}$ & $\begin{array}{l}0 \cdot 0 \\
2 \cdot 4\end{array}$ \\
\hline $\mathbf{L}$ & $\begin{array}{l}8 \\
22\end{array}$ & $\begin{array}{l}0.0 \\
0.0\end{array}$ \\
\hline $\mathbf{M}$ & $\begin{array}{r}9 \\
21\end{array}$ & $\begin{array}{l}0.0 \\
0.8\end{array}$ \\
\hline
\end{tabular}


found in the serum of one of the recipients (A) was almost certainly accounted for by the fact that she had received inoculations of brain vaccine 3 years earlier. Moreover, comparative vaccination experiments in animals showed that the potency of the same batch of DEV was much lower than that of an experimental vaccine produced from virus grown in BHK cells.

Since these results were published, Plotkin \& Clark (1971) have stated that in their experience laboratory workers immunized with duck embryo vaccine also have disappointingly low antibody levels and pointed out that there are even less controlled data about the protective effect of this vaccine in man than there are about nervous tissue vaccines. Duck embryo vaccine is, however, regarded as safer than nervous tissue vaccines, and the incidence of neurological complications during or after postexposure treatment has been only $1 / 25,000$. Only one death has been reported that could have been connected with vaccination in 172,000 vaccinees (Abdussalam \& Bögel, 1971). Local reactions are common, and in some recipients severe allergic reactions have occurred (Cowdrey, 1966). Nevertheless, duck embryo vaccine remains the recommended vaccine for both post- and pre-exposure vaccination of man (W.H.O., 1966) and is the post-exposure vaccine most used in the U.S.A. (Abdussalam \& Bögel, 1971).

\section{(c) Tissue culture vaccines}

The first experimental vaccines were produced in primary cultures of hamster kidney cells (Fenje, 1960; Ott \& Heyke, 1962) and Cabasso et al. (1965) described the production of Flury LEP vaccine in chick embryo fibroblasts. Fenje's virus strain was passaged by Abelseth (1964a and b) in chick embryos and then adapted to pig kidney cells. This is the ERA strain of rabies vaccine which, used without inactivation, has been shown in challenge tests to produce immunity for up to 5 years in dogs and 4 years in cats (Lawson \& Crawley, 1972). However, like other live vaccines, it is not acceptable for use in countries where the disease is not endemic.

Many workers have used hamster kidney cell lines for the production of rabies vaccines for animal use. In 1967 Petermann et al., using the NIL line of hamster fibroblasts and a fixed virus strain from the Wistar Institute, prepared a vaccine inactivated with BPL. This vaccine was shown to have good immunogenicity for dogs, cats and cattle and is in fact the vaccine imported into Britain for use in quarantine kennels. More recently, Crick \& Brown (1971) have shown that Flury LEP virus grown in BHK 21 cells and inactivated with acetylethyleneimine (AEI) is also an excellent immunogen for dogs and cattle. This experimental vaccine is now also produced at the Animal Virus Research Institute, Pirbright, in suspended cell culture (Chapman \& Ramshaw, personal communication). The Pasteur strain of virus, also grown in BHK 21 cells in either monolayers or suspended culture, has been used both as a live and a killed vaccine for animals (Atanasiu, Ribeiro \& Tsiang, 1972).

All the hamster kidney vaccines are highly antigenic and typical results are shown in Table 2. It is interesting to compare the response of dogs to one dose of BHK 21 vaccine with the response of humans to fourteen doses of DEV (Table 1).

The speed with which the new veterinary vaccines have been developed has unfortunately not been matched by similar progress in the human field. Requirements for a cell substrate for use in humans are much more exacting, and most licensing authorities will consider only primary cultures of embryonic tissue from carefully selected stock or strains of diploid cells of human origin. Tissue culture systems so far suggested for human use include primary hamster kidney cells (Kissling \& Reese, 1963; Fenje \& Pinteric, 1966), Syrian hamster kidney cells and sheep embryo kidney (Selimov \& Aksenova, 1966), chick embryo fibroblasts (Kondo, in press) and the human diploid cell strain WI-38 (Wiktor, Fernandes \& Koprowski, 1964). The Canadian vaccine, in which the virus is inactivated with formalin (Fenje, 1971), and the Russian vaccine (Selimov et al., 1969) are both licensed for use in man. The Canadian vaccine is used for pre-exposure immunization and has been tested experimentally in simulated post-exposure treatment, while the Russian

TABle 2. Antibody response in dogs to AEI-inactivated BHK rabies vaccine (from Crick \& Brown, 1971)

\begin{tabular}{|c|c|c|c|c|c|}
\hline \multirow[b]{2}{*}{ Vaccine schedule } & \multicolumn{5}{|c|}{$\begin{array}{l}\text { Log virus neutralized* by } \\
0.015 \mathrm{ml} 1 / 10 \text { serum }\end{array}$} \\
\hline & 3 weeks $\dagger$ & 7 weeks & 10 weeks & 28 weeks & 52 weeks \\
\hline $\begin{array}{l}1 \mathrm{ml} \text { vaccine } \\
\text { Two doses of } 1 \mathrm{ml} \\
\text { vaccine } 7 \text { weeks apart }\end{array}$ & $\begin{array}{l}2 \cdot 2 \\
1 \cdot 9\end{array}$ & $\begin{array}{l}1 \cdot 5 \\
1 \cdot 7\end{array}$ & $\begin{array}{l}2 \cdot 3 \\
4 \cdot 6\end{array}$ & $\begin{array}{l}2 \cdot 2 \\
4 \cdot 2\end{array}$ & $\begin{array}{l}1 \cdot 6 \\
3 \cdot 8\end{array}$ \\
\hline
\end{tabular}

* The neutralizing activity is the average of four sera in each group.

$\uparrow$ Time after first inoculation. 
vaccine has actually been used for post-exposure treatment with good results (Fenje, 1971).

Considerable interest was aroused by the first report of Wiktor et al. (1964) that the Flury HEP rabies virus grown in the human diploid cell strain, WI-38, was highly antigenic for monkeys. Moreover, inactivated vaccines from two strains of fixed virus adapted to WI-38 cells were also highly antigenic in mice. Thus, the production of an anti-rabies vaccine for man which was both effective and safe at last seemed feasible. Wiktor \& Koprowski (1965) extended these vaccine trials to groups of ten monkeys and showed once more that HEP virus grown in WI-38 cells was apparently much more antigenic for this species than HEP virus grown in chick embryo. In the same series of experiments they also showed that a fixed strain of virus (PM) grown in human diploid cells and inactivated with BPL stimulated a better antibody response in monkeys than DEV (Table 3). These results may be criticised on the grounds that in only one of the tests (using the live HEP virus grown in WI-38 cells) was a single dose of vaccine used, so that, as in the majority of rabies vaccine trials, the primary antigenic content of each vaccine was never measured. Furthermore, the WI-38 vaccines were given by what may well be the more sensitive intramuscular route, whereas the DEV was given subcutaneously. Koprowski (1967), describing trials in which $10^{7}$ 'man infective doses' were given intramuscularly into the neck muscles of vaccinated animals, claimed that an antibody titre of $1: 80$ or more assured protection against challenge. Antibody titres of this level or greater were achieved using WI-38 vaccines (Table 3 ) and the way was now open for clinical trials in man'.

However, there are difficulties in the large-scale production of WI-38 vaccines, and in laboratories throughout the world, including our own (Crick \& Hunter, unpublished), it has been found that WI-38 cells produce relatively low yields of virus, so that without prior concentration the killed vaccines at often no better antigenically than duck embrya vaccine. Wiktor et al. (1969) admitted that the antigenicity of the new vaccines was usually very litte higher than that of a standard vaccine (Referenge rabies vaccine, Lot No. 173, supplied by the Division of Biological Standards, National Institutes: of Health, Bethesda, U.S.A.) and it is now general accepted that vaccines produced in WI-38 cells wiff require concentration before use.

However, two important observations were mads with concentrated WI-38 vaccines. First, Wiktơr (1971) showed that more monkeys were protectegp against challenge by a single dose of concentrated WI-38 vaccine than by a sin gledose of either duch embryo vaccine or the standard vaccine (Table 4): Second, Wiktor (1971) showed that a single dose of WI-38 vaccine concentrate given to monkeys after experimental exposure to virus gave rather bettêf protection against the disease than fourteen daik doses of duck embryo vaccine (Table 5). The pro duction of WI-38 vaccine concentrates has, however. been criticised on the grounds of expense, but ths enormous advantages of having safe, single-dos vaccine therapy after exposure cannot be ovetr estimated. Clinical trials of the vaccines in humans have been started and preliminary results giverob both Bahmanyar and Kaplan (in press).

\section{Combined serum-vaccine prophylaxis for man}

Experimental justification for including antiseru市 at the beginning of the post-exposure course vaccine, thus providing an early antibody cover, was obtained in protection studies in mice, hamsters and guinea-pigs (Habel, 1945, 1954; Koprowski, Va⿳⺈⿴囗十灬 der Scheer \& Black, 1950; Koprowski \& Black 1954). A unique field trial which showed tha passively administered antibody could indeed be valuable in post-exposure therapy was carried out Iran in 1954. Of five people severely bitten in the

TABLE 3. Antibody response in monkeys immunized with rabies vaccine (from Wiktor \& Koprowski, 1965)

\begin{tabular}{|c|c|c|c|c|c|c|c|}
\hline \multicolumn{2}{|c|}{ Vaccination } & \multicolumn{6}{|c|}{$\begin{array}{l}\text { Neutralizing titre of rabies- } \\
\text { antibodies in sera of monkeys }\end{array}$} \\
\hline Type of vaccine & $\begin{array}{l}\text { No. of } \\
\text { doses }\end{array}$ & 1 & 7 & $\begin{array}{c}\text { Days } \\
14\end{array}$ & $\begin{array}{l}\mathrm{r} \mathrm{vac} \\
28\end{array}$ & $\begin{array}{l}\text { ation } \\
56\end{array}$ & 135 \\
\hline $\begin{array}{l}\text { HEP grown in } \\
\text { WI-38 cells }\end{array}$ & $\begin{array}{l}7 \\
3 \\
1\end{array}$ & $\begin{array}{l}<10^{*} \\
<10 \\
<10\end{array}$ & $\begin{array}{r}144 \\
82 \\
73\end{array}$ & $\begin{array}{l}864 \\
288 \\
224\end{array}$ & $\begin{array}{l}592 \\
232 \\
115\end{array}$ & $\begin{array}{r}325 \\
132 \\
53\end{array}$ & $\begin{array}{l}500 \\
224 \\
120\end{array}$ \\
\hline $\begin{array}{l}\text { PM/BPL grown } \\
\text { in WI-38 cells }\end{array}$ & $\begin{array}{l}7 \\
3\end{array}$ & $\begin{array}{l}<10 \\
<10\end{array}$ & $\begin{array}{l}33 \\
19\end{array}$ & $\begin{array}{r}104 \\
48\end{array}$ & $\begin{array}{l}65 \\
26\end{array}$ & $\begin{array}{l}31 \\
15\end{array}$ & $\begin{array}{l}35 \\
22\end{array}$ \\
\hline $\mathrm{HEP} / \mathrm{CE}$ & 3 & $<10$ & 11 & 19 & 12 & 12 & 一 \\
\hline DEV & 7 & $<10$ & 18 & 29 & 12 & 6 & - \\
\hline
\end{tabular}

* Figures indicate average titres for each group of animals. 
TABLE 4. Antibody response and challenge results* in rhesus monkeys vaccinated with one injection of experimental vaccine produced in WI-38 cells (from Wiktor, 1971)

\begin{tabular}{lcrrrr}
\hline & \multicolumn{6}{c}{ Mean antibody titres (days) } \\
\cline { 2 - 6 } Vaccine type & 6 & 19 & 31 & 73 & $\begin{array}{c}\text { Mortality } \\
\text { ratios }\end{array}$ \\
\hline DEV & 10 & 2 & 2 & $<2$ & $5 / 5$ \\
NIH Ref 173 & $10 \dagger$ & 5 & 3 & 3 & $4 / 5$ \\
WI-38 (1) & 140 & 350 & 230 & 95 & $0 / 5$ \\
W1-38 (2) & 290 & 780 & 470 & 470 & $1 / 5$ \\
Control & - & - & - & 2 & $5 / 5$ \\
\hline
\end{tabular}

* All animals were injected with $1 \mathrm{ml}$ of vaccine and challenged 73 days later.

$\dagger$ One monkey developed high antibody titres and survived challenge. This animal was not included in the calculation of mean antibody level.

TABle 5. Post-exposure evaluation of human vaccines in rhesus monkeys. SN antibody titres and challenge results (from Wiktor, 1971)

\begin{tabular}{|c|c|c|c|c|c|}
\hline \multirow[b]{2}{*}{ Vaccine type } & \multicolumn{3}{|c|}{ Antibody levels (days) } & \multicolumn{2}{|c|}{ Mortality } \\
\hline & 3 & 7 & 15 & Days & Ratio \\
\hline $\begin{array}{l}\text { DEV } \\
\text { Fourteen daily innoculations }\end{array}$ & $\begin{array}{l}<2 \\
<2 \\
<2 \\
<2 \\
<2\end{array}$ & $\begin{array}{r}125 \\
33 \\
33 \\
125 \\
45\end{array}$ & $\begin{array}{r}-33 \\
95 \\
160 \\
45\end{array}$ & $\begin{array}{l}10 \\
33 \\
32 \\
31\end{array}$ & $4 / 5$ \\
\hline WI-38-One dose & $\begin{array}{l}<2 \\
<2 \\
<2 \\
<2 \\
<2 \\
<2 \\
<2\end{array}$ & $\begin{array}{r}56 \\
25 \\
33 \\
160 \\
25 \\
70 \\
280\end{array}$ & $\begin{array}{r}- \\
280 \\
280 \\
800 \\
350 \\
1400\end{array}$ & $\begin{array}{l}10 \\
11 \\
16\end{array}$ & $3 / 7$ \\
\hline Controls & $\begin{array}{l}<2 \\
<2 \\
<2 \\
<2 \\
<2\end{array}$ & $\begin{array}{l}<2 \\
<2 \\
<2 \\
<2 \\
<2\end{array}$ & $\begin{array}{r}<\overline{2} \\
95 \\
<2 \\
<2\end{array}$ & $\begin{array}{l}11 \\
27 \\
27 \\
28\end{array}$ & $4 / 5$ \\
\hline
\end{tabular}

head and neck by a rabid wolf and given a course of Fermi vaccine, three died from rabies. In contrast, twelve out of thirteen people survived after being similarly wounded but treated with a dose of antiserum in addition to vaccine (Baltazard \& Bahmanyar, 1955). Despite the small numbers involved in this trial, immune serum was recommended subsequently together with vaccination for the treatment of humans after severe exposure to rabies (W.H.O. Expert Committee on Rabies, 1957, 1966; Plotkin \& Clark, 1971).

Although Habel (1966) expressed his confidence in the combined use of antiserum and vaccine, other workers have been less convinced of its value (Wiktor, Lerner, \& Koprowski, 1971) and treatment failures have been recorded (Anderson, Daly \& Kidd, 1966; Dehner, 1970). Habel (1966) and Atanasiu et al. (1956, 1957, 1961, 1967) found that the antibody present in the injected serum tends to inhibit the active immunity stimulated by vaccination, an effect which Wiktor et al. (1971) were able to demonstrate experimentally in rabbits. Furthermore, the use of equine serum in humans may cause anaphylactic reactions and serum sickness (Karliner \& Belaval, 1965). Although the successful production and clinical trial of human rabies immune globulin was reported by Cabasso et al. (1971), it is difficult to imagine that such material will be generally available until there are better vaccines for its production.

\section{Future considerations}

(a) Virus subunits for human vaccines

Because of the difficulties in purifying nervous tissue vaccines, the poor antigenicity of duck embryo vaccine and the problems inherent in the production of effective vaccines from human diploid cells, it may seem over-ambitious to consider the 
production of a purified subunit vaccine for human prophylaxis but, by using purified subunits as antigen, the notorious side effects which may accompany the use of the present-day vaccines would be avoided. Furthermore, the antigenic content of the vaccine could be determined very precisely. Perhaps in the future a purified subunit vaccine prepared from virus grown in cells such as BHK 21 could even be considered for human use!

Rabies virus, like vesicular stomatitis virus (VSV), is a member of the rhabdovirus group (Fig. 1) and might therefore be expected to resemble this virus not only in its morphology but also in structural, functional and immunological properties. The surface projections of VSV stimulate the production of neutralizing antibodies when inoculated into guineapigs, and there is an excess of these spikes or similar subunits in tissue culture harvests (Brown, Cartwright \& Almeida, 1966). More recently, suspensions of brain tissue and BHK 21 cells infected with rabies virus have been shown to contain immunizing subunits (Crick \& Brown, 1969, 1970b; Wiktor et al., 1969; Schlumberger, Wiktor \& Koprowski, 1970). Following the work of Brown, Cartwright \& Smale (1967) and Cartwright, Smale \& Brown (1970) with VSV, Crick \& Brown (1970b) examined the effect of Tween/ether and detergents on rabies virus. Each reagent depressed the infectivity of the rabies virion and the effect on the morphology of the virus is shown in Fig. 2. In contrast to the results obtained with VSV (Brown et al., 1967), Tween/ether did not appear to remove the spikes. However, the results obtained by detergent treatment were similar to those described for VSV. After the addition of sodium dodecyl sulphate (SDS) no structural entities could be identified by electron microscopy but, when Nonidet P40 or sodium deoxycholate (DOC) was used, the virus was disrupted to give, in the case of Nonidet, skeleton-like structures with the spikes removed and, in the case of DOC, strings of ribonucleoprotein. When the virus was inactivated with AEI, disrupted and then inoculated into mice, neutralizing antibodies were produced in all cases except for the SDS-treated material (Table 6).

Another potential subunit vaccine for rabies has since been described by Schneider, Horzinek \& Novický (1971). These workers used saponin to inactivate and disrupt the virus and showed that the product was highly immunogenic for mice. Tint (in press), using virus grown in WI-38 cells, separated the glycoprotein from the lipid by treatment with Tween 80 and tri(n-butyl)phosphate to produce a very promising vaccine which has been tried in humans. That the glycoprotein is in fact the antigen which can induce the formation of neutralizing antibodies and protect animals against challenge has now been shown by Wiktor et al. (1973).

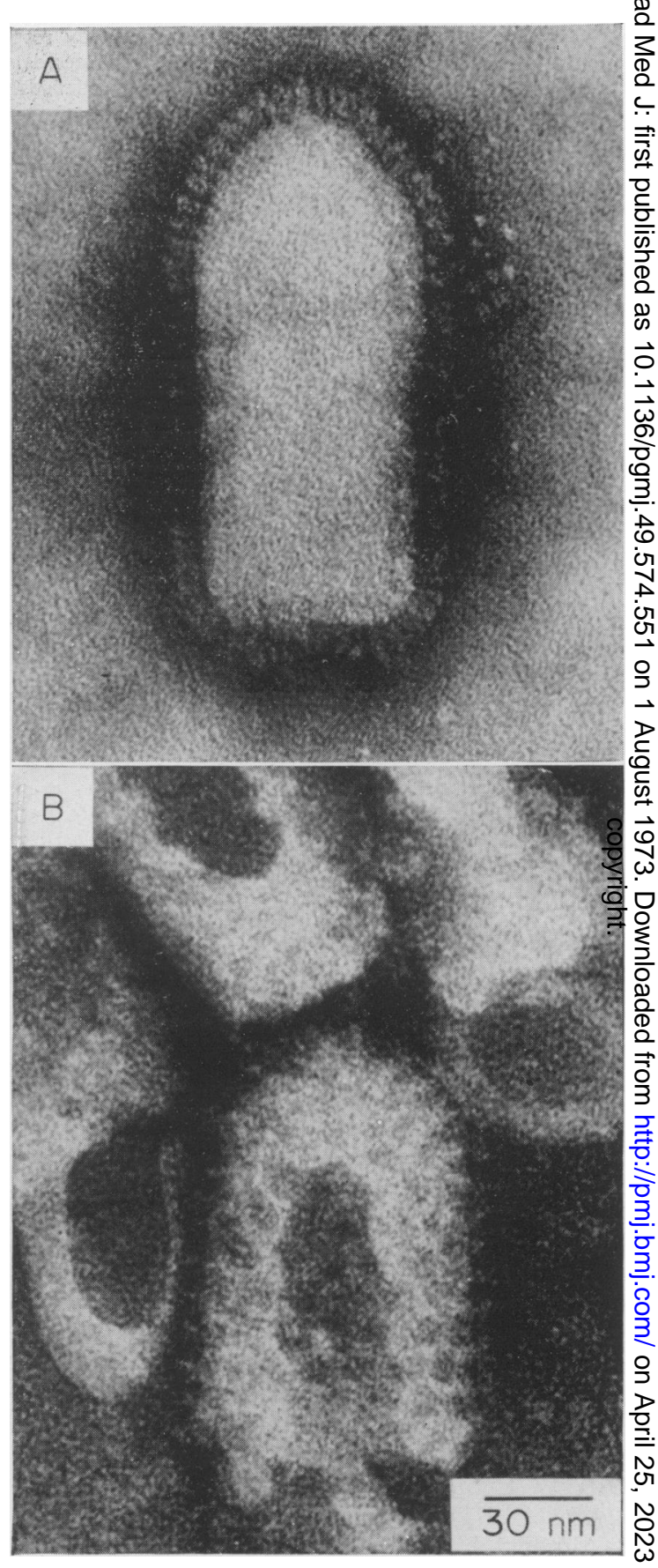

FIG. 1. Electron micrographs of: (A) vesicular stomatitis virus, strain Indiana C; (B) rabies virus, strain Flury LEP.

The production of a subunit vaccine against rabies 0 is therefore possible. However, Neurath \& Rubin (1971), while agreeing that in many ways the use of $\stackrel{\overparen{D}}{\stackrel{\mathbb{D}}{ }}$ 


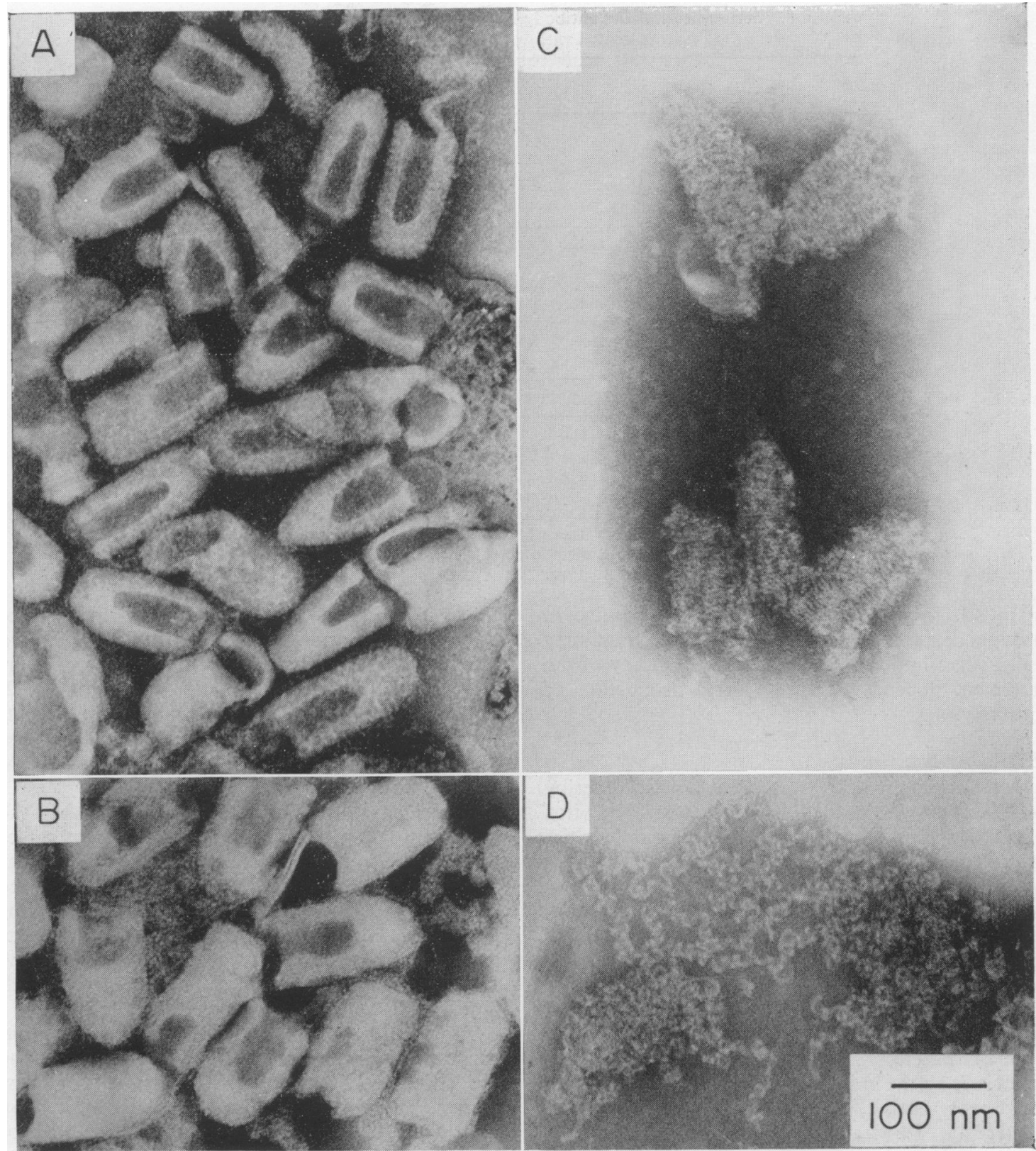

FIG. 2. Electron micrographs showing the effect of various treatments on rabies virus. (A) untreated virus; (B) Tween-ether; (C) Nonidet; (D) sodium deoxycholate.

viral structural protein for immunization against viral diseases is desirable, showed that there is considerable evidence that the most efficient antigen for the production of virus neutralizing antibodies is the virus itself. An interesting observation in this connection was recently made in our laboratory. We found that, when the antibody response to a single dose of a DOC-disrupted rabies vaccine was compared with that to the inactivated vaccine from which it was derived, not only was the antibody response to the disrupted vaccine somewhat lower but it was also considerably delayed. Direct conversion to IgG antibody occurred, and at no stage did we detect any IgM antibody (Table 7) (Brown \& Crick) 
TABLE 6. Serum neutralizing antibody in mice 21 days after inoculating rabies virus treated with various reagents

\begin{tabular}{lcc}
\hline \multicolumn{1}{c}{ Reagent } & $\begin{array}{c}\text { Log depression } \\
\text { of infectivity }\end{array}$ & $\begin{array}{c}\text { Neutralizing activity* in } \\
0.015 \text { ml of } 1 / 10 \text { serum }\end{array}$ \\
\hline None & - & $2 \cdot 4$ \\
Tween-ether & $3 \cdot 4$ & $2 \cdot 6$ \\
$0.1 \%$ Nonidet & $2 \cdot 8$ & $2 \cdot 1$ \\
$0.1 \%$ Sodium deoxycholate & $1 \cdot 6$ & $2 \cdot 2$ \\
$0.1 \%$ Sodium dodecyl sulphate & $4 \cdot 2$ & 0 \\
\hline
\end{tabular}

* The neutralizing activity is the average of five sera in each group.

TABLE 7. Antibody response in guinea-pigs to deoxycholatetreated inactivated rabies virus

\begin{tabular}{llll}
\hline & \multicolumn{3}{c}{$\begin{array}{c}\text { Log virus neutralized by } \\
0.015 \mathrm{ml} \mathrm{1/20} \text { serum }\end{array}$} \\
\cline { 2 - 4 } Antigen & 6 days $\dagger$ & 13 days & 21 days \\
\hline Virus & 3.0 & 3.6 & 2.6 \\
Virus + DOC & $1.5(\mathrm{ME}) *$ & $2.4(\mathrm{ME})$ & $2.6(\mathrm{ME})$ \\
& 0.8 & 0.7 & 2.0 \\
& $1.0(\mathrm{ME})$ & $0.3(\mathrm{ME})$ & $2.0(\mathrm{ME})$ \\
\hline
\end{tabular}

* These sera were treated with $0.1 \mathrm{M}$ mercaptoethanol before use in the neutralization test

$\dagger$ Time after inoculation.

in press). In view of the use of rabies vaccine in post-exposure therapy of humans, this point may be of some importance if in fact the efficacy of the treatment depends upon the early production of antibody.

\section{(b) Rabies-like viruses}

Although strains of rabies virus showing differing biological properties have been described, the virus has until recently been regarded by most authorities as a single serological entity unrelated to other members of the rhabdovirus group. So little antigenic variation has been found between strains that it has been standard practice to use the same strains throughout the world for the production of vaccines and antisera (Habel, 1966).

Recently, however, two viruses serologically and morphologically related to rabies were described by Shope et al. (1970). The first, Lagos Bat virus, was isolated from the brain of a fruit bat (Eidolon helvam) on Lagos Island, Nigeria, in 1956 (Boulger \& Porterfield, 1958). Three strains of the second virus, Mokola, including the reference strain IbAn 27377, were isolated in 1968 from the pooled lungs, liver, spleen, kidneys and heart of shrews (Crocidura sp.) captured in Ibadan, Nigeria. On the basis of complement fixation, serum neutralization tests and their mode of maturation, Shope et al. (1970) placed the two new viruses and rabies in a subgroup within the rhabdovirus group. Results of vaccination and challenge tests in mice with all three viruses confirmed that there was some antigenic relatedness between them (Tignor \& Shope, 1972).
The isolation, also in Ibadan, of a virus from the brain of a horse which had died from 'Staggers', $a^{\circ}$ disease resembling rabies, was described by Portep- $\vec{\theta}$ field, Hill \& Morris (1958). It was not until 19 however, that this virus was shown to be bullefi:shaped and to be related serologically to rabies (Porterfield, Armstrong \& Turner, personal communication).

Schneider \& Schoop (1972) suggested that the three Nigerian viruses are new serotypes of rabies $\stackrel{2}{\Rightarrow}$ differing from the classical virus in their outer coat components. They stated that experiments at the Federal Research Institute for Animal Virus Diseases in Tübingen, Germany, had shown that the newly discovered viruses and rabies itself had the same internal nucleoprotein component, which represented the group antigen.

The relevance of these findings to vaccination $\delta$ programmes in West Africa will depend on the $₹$ incidence, pathology and host range of the new 0 viruses. Three more strains of Mokola virus have been isolated, two of them from children, one of whom died (Kemp et al., 1972). The two human cases of Mokola were described by Kemp et al. or (1972), Familusi \& Moore (1972) and Familusi et $N$ al. (1972) and their evidence suggests that Mokola $\underset{\mathrm{N}}{\mathrm{N}}$ virus infection could be confused clinically with rabies and other paralytic conditions. Tignor \& Shope (1972) found that mice vaccinated with $\frac{0}{\varnothing}$ rabies virus were only poorly protected against the $\stackrel{\oplus}{\sim}$ reference strain of Mokola virus and pointed out 0 the relevance of this to the present situation, in which only the classical rabies vaccines are available. 
The same authors (Shope \& Tignor, 1971) discussed the possibility of a heterologous rabies vaccine or a successful combined vaccine regimen for areas such as West Africa. Furthermore, if the remarks of Schneider \& Schoop (1972) concerning the structural differences and similarities in this group of viruses are correct, a subunit vaccine containing the coat proteins of only one virus would be unable to provide the broad spectrum of immunity required in an area where several viruses of the rabies group were endemic.

In the last decade methods have become available whereby rabies virus grown in tissue culture can be purified and examined by chemical and physical techniques. The way is now open, therefore, for the detailed examination of structural relationships within the virus group. When this knowledge becomes available and the disease itself is better understood, it will be possible to decide on the public health measures, including vaccination, which should be used for the protection of domestic animals and the human population.

\section{Acknowledgments}

The author would like to thank Dr F. Brown for his advice in the preparation of this paper and $\mathrm{Mr} \mathrm{C}$. J. Smale for the electron micrographs.

\section{References}

Abdussalam, M. \& Bögel, K. (1971). The problem of antirabies vaccination. In: International Conference on the Application of Vaccines against Viral, Rickettsial and Bacterial Diseases of Man. Pan American Health Organization, W.H.O., Washington D.C. Scientific Publication No. 226 , p. 54.

Abelseth, M.R. (1964a) Propagation of rabies virus in pig kidney cell cultures. Canadian Veterinary Journal, $5,84$.

Abelseth, M.R. (1964b) An attenuated rabies vaccine for domestic animals produced in tissue culture. Canadian Veterinary Journal, 5, 279.

Afshar, A., Bahmanyar, M. \& Fayaz, A. (1972) A contribution to the detection of inapparent rabies in stray dogs. The Veterinary Record, 91, 562.

ANDERson, J.A., DALY, F.T. JR \& KidD, J.C. (1966) Human rabies after antiserum and vaccine post exposure treatment. Case reports and review. Annals of Internal Medicine, 64, 1297.

Atanasiu, P., Bahmanyar, M., Baltazard, M., Fox, J.P., Habel, K., Kaplan, M.M., Kissling, R.E., Komarov, A., Koprowski, H., Lépine, P., Gallardo, F. Perez \& SCHAEFFER, M. (1956) I. Rabies neutralizing antibody response to different schedules of sorum and vaccine inoculations in non-exposed persons. Bulletin of the World Health Organization, 14, 593.

Atanasiu, P., Bahmanyar, M., Baltazard, M., Fox, J.P., Habel, K., Kaplan, M.M., Kissling, R.E., Komarov, A., Koprowski, H., Lépine, P., Gallardo, F. Perez \& SCHAEFFER, M. (1957) II. Rabies neutralizing antibody response to different schedules of serum and vaccine inoculations in non-exposed persons. Bulletin of the World Health Organization, 17, 911.
Atanasiu, P., Cannon, D.A., Dean, D.J., Fox, J.P. Habel, K., Kaplan, M.M., Kissling, R.E., Koprowski, H., Lépine, P. \& Gallardo, F. Perez (1961) III. Rabies neutralizing antibody response to different schedules of serum and vaccine inoculations in non-exposed persons. Bulletin of the World Health Organization, 25, 103.

Atanasiu, P., Dean, D.J., Habel, K., Kaplan, M.M., Koprowski, H. LÉPINe, P. \& SERIÉ, C. (1967) IV. Rabies neutralizing antibody response to different schedules of serum and vaccine inoculations in non-exposed persons. Bulletin of the World Health Organization, 36, 361.

Atanasiu, P., Ribeiro, M. \& Tsiang, H. (1972) Vaccins antirabiques de culture cellulaire obtenus avec la souche Pasteur. Résultats de vaccination. Annales de l'Institut Pasteur, 123, 427.

BaER, G.M., Abelseth, M.K. \& Debbie, J.G. (1970) Oral vaccination of foxes against rabies. American Journal of Epidemiology, 93, 487.

BAER, G.M. \& Cleary, W.F. (1972) A model in mice for the pathogenesis and treatment of rabies. Journal of Infectious Diseases, 125, 520 .

Baltazard, M. \& Bahmanyar, M. (1955) Essai pratique du sérum antirabique chez les mordus par loups enragés. Bulletin of the World Health Organization, 13, 747.

BeLL, J.F. (1964) Abortive rabies infection. I. Experimental production in white mice and general discussion. Journal of Infectious Diseases, 114, 249.

BELL, J.F. (1967) Present concepts of the epidemiology of rabies. In: First International Conference on Vaccines against Viral and Rickettsial Diseases of Man. Pan American Health Organization, W.H.O., Washington D.C. Scientific Publication No. 147, p. 481 .

BLACK, J.G. \& LAwson, K.F. (1970) Sylvatic rabies studies in the silver fox (Vulpes vulpes). Susceptibility and immune response. Canadian Journal of Comparative Medicine, 34 309.

Boulger, L.R. \& Porterfield, J.S. (1958) Isolation of a virus from Nigerian fruit bats. Transactions of the Royal Society of Tropical Medicine and Hygiene, 52, 421.

Brown, F., Cartwright, B. \& Almeida, J.D. (1966) The antigens of vesicular stomatitis virus. I. Separation and immunogenicity of three complement-fixing antigens. Journal of Immunology, 96, 537.

Brown, F., Cartwright, B. \& Smale, C.J. (1967). The antigens of vesicular stomatitis virus. III. Structure and immunogenicity of antigens derived from the virion by treatment with Tween and ether. Journal of Immunology, 99, 171.

Bulletin of the World Health Organization (1954) 10. World Health Organization, Geneva.

Cabasso, V.J. (1966) Canine rabies vaccines. In: Proceedings of the National Rabies Symposium, p. 45. National Communicable Disease Center, U.S. Department of Health, Education and Welfare, Atlanta, Ga.

Cabasso, V.J., Loofburrow, J.C., Roby, R.E. \& AnuskieWICZ, W. (1971) Rabies immune globulin of human origin: preparation and dosage determination in non-exposed volunteer subjects. Bulletin of the World Health Organization, 45, 303.

Cabasso, V.J., Stebbins, M.R., Douglas, A. \& Sharpless, G.R. (1965) Tissue-culture rabies vaccine (Flury LEP) in dogs. American Journal of Veterinary Research, 26, 24.

Cartwright, B., Smale, C.J. \& Brown, F. (1970) Dissection of vesicular stomatitis virus into the infective ribonucleoprotein and immunizing components. Journal of General Virology, 7, 19.

Chalmers, A.W. \& Scott, G.R. (1969) Ecology of rabies. Tropical Animal Health and Production, 1, 33.

Center for Disease Control (1969) Public Health Service, U.S. Department of Health, Education and Welfare, Zoonoses Surveillance, Annual Summary-Rabies. 
Constantine, D.G. (1962) Rabies transmission by nonbite route. Public Health Reports, Washington, 77, 287.

CowDREY, S.C. (1966) Sensitization to duck-embryo rabies vaccine produced by prior yellow-fever vaccination. New England Journal of Medicine, 274, 1311.

CRICK, J. \& Brown, F. (1969) Viral subunits for rabies vaccination. Nature, 222, 92.

Crick, J. \& Brown, F. (1970a) Efficacy of rabies vaccine prepared from virus grown in duck embryos. Lancet, i, 1106.

Crick, J. \& Brown, F. (1970b) Small immunizing subunits in rabies virus. In: The Biology of the Large RNA Viruses (Ed. by R. D. Barry and B. W. J. Mahy), p. 133. Academic Press, London and New York.

Crick, J. \& Brown, F. (1971) An inactivated baby hamster kidney cell vaccine for use in dogs and cattle. Research in Veterinary Science, 12, 156.

DEAN, D. (1964) Studies on the low passage Flury strain of modified live rabies virus produced in embryonating chicken eggs and tissue culture. American Journal of Veterinary Science, 25, 756.

Dean, D.J. \& Sherman, I. (1962) Potency of commercial rabies vaccine used in man. Public Health Reports, Washington, 77, 705.

Debbie, J.B., Abelseth, M.K. \& Baer, G.M. (1972). The use of commercially available vaccines for the oral vaccination of foxes against rabies. American Journal of Epidemiology, 96, 231.

DeHNER, L.P. (1970) Human rabies encephalitis in Vietnam. Annals of Internal Medicine, 72, 375.

Dreeson, D.W., Eubanks, J.F. \& Behymer, D.E. (1970) Antibody responses in cattle vaccinated with various rabies vaccines. Journal of the American Veterinary Medical Association, 157, 826.

FAMILUSI, J.B. \& MoORE, D.L. (1972) Isolation of a rabies related virus from the cerebrospinal fluid of a child with 'aseptic meningitis'. African Journal of Medical Science, 3, 93.

Familusi, J.B., Osunkoya, B.O., Moore, D.L., Kemp, G.E. \& FABIYI, A. (1972) A fatal human infection with Mokola virus. American Journal of Tropical Medicine and Hygiene, 21, 959.

Fenje, P. (1960) A rabies vaccine from hamster kidney tissue cultures; preparation and evaluation in animals. Canadian Journal of Microbiology, 6, 605.

FENJE, P. (1971) The status of existing rabies vaccines. In: International Conference on the Application of Vaccines against Viral, Rickettsial and Bacterial Diseases of Man. Pan American Health Organization, W.H.O., Washington D.C. Scientific Publication No. 226, p. 54.

Fenje, P. \& Pinteric, L. (1966) Potentiation of tissue culture rabies vaccine by adjuvants. American Journal of Public Health, 56, 2106.

Fox, J.P., Koprowski, H., Conwell, D.P., Black, J. \& GELFAND, H.M. (1957) Studies of antirabies immunization of man. Observations with HEP Flury and other vaccines with and without hyperimmune serum in primary and recall immunizations. Bulletin of the World Health Organization, 17, 869.

Fredrickson, L.E., Willett, J.C., Smith, J.E. \& Price, E.R. (1953) Mass immunisation of dogs against rabies. Its influence on a rabies epizootic in St Louis. American Journal of Public Health, 43, 399.

Fuenzalida, F. \& Palacios, R. (1955) Un métoda mejorado en la preparación de la vacuna antirrábica. Boletin del Instituo Bacteriológico de Chile, 8, 3.

GisPen, R. \& SAATHOF, B. (1965) Neutralizing and fluorescent antibody response in man after antirabies treatment with suckling rabbit brain vaccine. Archiv für die gesamte Virusforschung, 15, 377.
Gispen, R., SchittmanN, G.T.P. \& SAAThof, B. (1965) Rabies vaccine derived from suckling rabbit brain. Archiv für die gesamte Virusforschung, 15, 366.

GREenBERG, M. \& CHILDRESS, J. (1960) Vaccination against rabies with duck embryo and Semple vaccines. Journal of $\equiv$ the American Medical Association, 173, 77.

HABEL, K. (1945) Public Health Reports, Washington, 60, 545.

HABEL, K. (1954) Antiserum in the prophylaxis of rabies. Bulletin of the World Health Organization, 10, 781.

HABEL, K. (1966) Post-exposure vaccination and antiserum prophylaxis of rabies in man. In: Proceedings of the National Rabies Symposium, p. 89. National Communicable Disease Center, Atlanta, Ga.

HatTWICK, M.A.W., WeIs, T.T., STEChSchultze, C.J., BAER, G.M. \& GREGG, M. (1972) Recovery from rabies. A case report. Annals of Internal Medicine, 76, 931.

Held, J.R. \& AdARos, H.L. (1971) Neurological disease in man following administration of suckling mouse brain antirabies vaccine. Bulletin of the World Health Organization, 46, 321.

HubBaRD, H.B. (1969) Rabies immunity in vaccinated cattle. Proceedings of 73rd Annual Meeting of U.S. Animal Health Association, p. 307.

JoHnSON, H.N. (1954) Experimental studies on the duration of immunity in dogs vaccinated against rabies. Bulletin of the World Health Organization, 10, 725.

KAPLAN, C. \& TURNER, G.S. (1968) Removal of encephalitogenicity from extracts of normal rabbit central nervous system by treatment with fluorocarbon. Nature, 219, 445.

KAPLAN, M.M. (1969) Epidemiology of rabies. Nature, 221, 421.

KARLINER, J.S. \& BELAVAL, G.S. (1965) Incidence of reactions following administration of antirabies serum. Journal $\$$ the American Medical Association, 193, 359.

Kemp, G.E., Causey, O.R., Moore, D.L., Odelola, A. FABIYI, A. (1972) Mokola virus. Further studies of Ib An 27377, a new rabies-related etiologic agent of zoonosis in Nigeria. American Journal of Tropical Medicine and Hygiene, 21, 356.

Kissling, R.E. \& ReESE, D.R. (1963) Anti-rabies vaccine of tissue culture origin. Journal of Immunology, 91, 362.

KoProwsKI, H. (1967) Vaccines against rabies: present and future. In: Proceedings of First International Congress on Vaccines against Viral and Rickettsial Diseases of Man. Pan American Health Organization, W.H.O., Washington D.C. Scientific Publication No. 147, p. 488.

Koprowski, H. (1971) Pre- and post-exposure prophylaxis: present status and current trends. In: Rabies (Ed. by Yasuito Nagano and Fred M. Davenport), p. 111. University Park Press, Baltimore, London, Tokyo.

Koprowski, H. \& Black, J. (1952) Studies on chick-embryo adapted rabies virus. III. Duration of immunity in vaccinated dogs. Proceedings of the Society for Experimental Biology and Medicine, 80, 410.

KoprowsKI, H. \& BLACK, J. (1954) Studies on chick-embryo adapted rabies virus. V. Protection of animals with antiserum and living attenuated virus after exposure to a street strain of rabies virus. Journal of Immunology, 72,85 .

KoPRowski, H. \& Cox, H.R. (1948) Studies on chickembryo adapted rabies virus. I. Culture characteristics and pathogenicity. Journal of Immunology, 60, 533.

Koprowski, H., VAN Der Scheer, J. \& BlaCK, J. (1950). Use of hyperimmune antirabies serum concentrate in experimental rabies. American Journal of Medicine, 8, 412.

Krause, W.W. (1966) The pathogenesis of rabies. Symposium Series in Immunobiological Standardization, 1, 153. Karger, Basel.

LAVENDER, J.F. (1970) Purified rabies vaccine (suckling rat brain origin). Applied Microbiology, 19, 923. 
LAwson, K.F. \& CRAwley, J.F. (1972) The ERA strain of rabies vaccine. Canadian Journal of Comparative Medicine, 36, 339.

LÉPINE, P. (1966) Fermi type vaccine. In: Laboratory Techniques in Rabies. Monograph series, World Health Organization, Geneva. No. 23, 10, 97.

Macpherson, I. \& Stoker, M. (1962) Polyoma transformation of hamster cell clones-an investigation of genetic factors affecting cell competence. Virology, 16, 147.

MEYER, K.F. (1954) Can man be protected against rabies? Bulletin of the World Health Organization, 10, 845.

Matsumoto, S. (1970) Rabies virus. In: Advances in Virus Research, 16, 257. Academic Press, New York.

Neurath, A.R. \& Rubin, B.A. (1971) Recent developments in preparing vaccines from viral structural components. In: Viral Structural Components as Immunogens of Prophylactic Value, Vol. 4, VII, 54. Monographs in Virology. Karger, Basel,

OTt, G.L. \& Heyke, B. (1962) Preliminary trials of a new tissue culture rabies vaccine. Veterinary Medicine, 57, 158.

PARISH, H.J. (1965) A History of Immunization, Vol. 4, p. 52. E. \& S. Livingstone Ltd, Edinburgh and London.

Pasteur, L. (1885) Méthode pour prévenir la rage après morsure. Compte rendu hebdomadaire des Séances de l'Académie des Sciences, 101, 765.

PeCK, F.B. JR, Powell, H.M. \& Culbertson, G.C. (1956) Duck-embryo rabies vaccine. Study of fixed virus vaccine grown in embryonated duck eggs and killed with betapropiolactone (BPL). Journal of the American Medical Association, 162, 1373.

Petermann, H.G., Lang, R., Branche, R. \& Soulebot, J.P. (1967) Un nouveau vaccin antirabique préparé avec du virus fixe produit sur culture de cellules et inactive. 18ième Congrès Mondial Vétérinaire, Paris, 1, 227.

Plotkin, S.A. \& Clark, H.F. (1971) Prevention of rabies in man. Journal of Infectious Diseases, 123, 227.

Porterfield, J.S., Hill, D.H. \& Morris, A.D. (1958) Isolation of a virus from the brain of a horse with 'Staggers' in Nigeria. British Veterinary Journal, 114, 425.

REPORT OF THE COMMITTEE OF INQUiRY ON RABIES. Final Report (1971). Her Majesty's Stationery Office, London, 4, 18.

SCHINDleR, R. (1966) Pathogenesis of rabies infection. Symposia Series in Immunobiological Standardization, 1, 47. Karger, Basel.

SCHNEIDER, L.G., Horzinek, M. \& Novicky, R. (1971) Isolation of a haemagglutinating, immunizing and noninfectious subunit of the rabies virion. Archiv für die gesamte Virusforschung, 34, 360.

SCHNeIDer, L.G. \& Schoop, U. (1972) Pathogenesis of rabies and rabies-like viruses. Annales de l'Institut Pasteur, 123, 469.

SChlumberger, H.D., WiktoR, T.J. \& KoproWSKI, H. (1970) Antigenic and immunogenic properties of components contained in rabies virus-infected tissue culture fluids. Journal of Immunology, 105, 291.

SCHMIDT, R.C. \& Sikes, R.K. (1968) Immunization of foxes with inactivated-virus rabies vaccine. American Journal of Veterinary Research, 29, 1843.

Schwab, M.P., Fox, J.P., Conwell, D.P. \& Robinson, T. A. (1954) Avianized rabies vaccination in man. Bulletin of the World Health Organization, 10, 823.

Selimov, M.A. \& Aksenova, T.A. (1966) Tissue culture antirabic vaccine for human use. Symposia Series in Immunobiological Standardization, 1, 377. Karger, Basel.

Selimov, M.A., Aksenova, T.A., Klyueva, E.V., Rakhimova, F.I., Mirzoeva, S., Kamenetskaya, I.P., Priyatkina, A.N., Gosteva, E.P., Krupenin, L.M., MisChenko, N.G., Savelieva, A.N., Pronyuschkina, O.B.,
Shafaroba, T.A. \& Shekhtman, I.A. (1969) The use of cultural rabies vaccine for therapeutic immunization of man. Zhurnal mikrobiologii, épidemiologii i immunobiologii, 46(ii), 63.

Shope, R.E., Murphy, F.A., Harrison, A.K., Causey, O.R., Kemp, G.E., Simpson, D.I.H. \& Moore, D.L. (1970) Two African viruses serologically and morphologically related to rabies virus. Journal of Virology, 6, 690.

SHOPE, R.E. \& TIGNOR, G.H. (1971) Rabies and serologicallyrelated viruses from Africa. In: Rabies (Ed. by Yasuito Nagano and Fred M. Davenport), p. 53. University Park Press, Baltimore.

SIKES, R.K. (1971) Evaluation of canine rabies vaccines. In: Rabies (Ed. by Yasuito Nagano and Fred M. Davenport), p. 343. University Park Press, Baltimore.

Sikes, R.K., Cleary, W.F., Koprowski, H., Wiktor, T.J. \& KAPLAN, M.M. (1971) Effective protection of monkeys against death from street virus by post exposure administration of tissue-culture rabies vaccine. Bulletin of the World Health Organization, 45, 1.

Sikes, R.K. \& LARGHI, O.P. (1967) Purified rabies vaccine: development and comparison of potency and safety with two human rabies vaccines. Journal of Immunology, 99, 545.

Svet-MoldavskiJ, G.J., Andjaparidze, O.G., Unanov, S.S., KaraKajumcan, M.K., SVet-MoldavyKaJa, I.A., MucniK, L.S., Hieninson, M.A., Ravkina, L.I., MTVareLIDZE, A.A., Volkova, O.F., Kriegshaber, M.R., Kalinkina, A.G., Salita, T.V., Klimovickaja, V.I., Bondaletova, I.N., RoJHel, V.M., Kiseleva, I.S., Levcenko, E.N., Marennikova, S.S. \& Leonidova, S.L. (1965) An allergen-free antirabies vaccine. Bulletin of the World Health Organization, 32, 47.

Tierkel, E. (1949) Preliminary observations in the comparative prophylactic vaccination of dogs against rabies with living virus vaccines and phenolized vaccine. American Journal of Veterinary Research, 10, 361.

TIGNOR, G.H. \& SHOPE, R.E. (1972) Vaccination and challenge of mice with viruses of the rabies subgroup. Journal of Infectious Diseases, 125, 322.

TURNer, G.S. (1969) Rabies vaccines. British Medical Bulletin, 25, 136.

TURNER, G.S. (1972) Rabies virus and interferon. Journal of Hygiene, 70, 445.

TURNER, G.S. (1973) Humoral and cellular immune responses of mice to rabies and smallpox vaccines. Nature New Biology, 241, 90.

UMENo, S. \& DoI, Y. (1921) A study in the antirabic vaccination of dogs. Kitasato Archives of ExperimentalMedicine, 4, 89.

Veeraraghavan, N. (1969) Rabies A. The value of 5 per cent Semple vaccine in human treatment-comparative mortality among the treated and untreated. Pasteur Institute of Southern India, Coonoor. Annual Report of the Director, 1968, and Scientific Report, 1969, p. 35.

WikToR, T.J. (1971) New vaccines and the future of rabies prophylaxis. In: International Conference on the Application of Vaccines against Viral, Rickettsial and Bacterial Diseases of Man. Pan American Health Organization, W.H.O., Washington, D.C. Scientific Publication No. 226, p. 66.

Wiktor, T.J., Fernandes, M.V. \& Koprowski, H. (1964) Cultivation of rabies virus in human diploid cell strain W1-38. Journal of Immunology, 93, 353.

Wiktor, T.J., Györgi, E., Schlumberger, H.D., Sokol, F. \& KoprowsKI, H. (1973) Antigenic properties of rabies virus components. Journal of Immunology, 110, 269.

WikTOR, T.J. \& Koprowski, H. (1965) Successful immunization of primates with rabies vaccine prepared in human diploid cell strain W1-38. Proceedings of the Society for Experimental Biology and Medicine, 118, 1069. 
WIKTOR, T.J., LERNER, R.A. \& KoPROWSKI, H. (1971) Inhibitory effect of passive antibody on active immunity induced against rabies by vaccination. Bulletin of the World Health Organization, 45, 747.

Wiktor, T.J., Postic, B., Ho, M. \& Koprowski, H. (1972) Role of interferon in the protective activity of rabies vaccines. Journal of Infectious Diseases, 126, 408.

WikToR, T.J., SOKOL, F., KUWERT, E. \& KoProwski, H. (1969) Immunogenicity of concentrated and purified rabies vaccines of tissue culture origin. Proceedings of the Society for Experimental Biology and Medicine, 131, 799.
Winkler, W.G., BAKer, E.F. JR \& Hoskins, C.C. (1972) An outbreak of non-bite transmitted rabies in a laboratory animal colony. American Journal of Epidemiology, 95, 267

World Health Organization Expert Committee on RABIES. Fourth Report (1957) Technical Report Series No. 121. World Health Organization, Geneva.

World Health Organization Expert Committee Rabies. Fifth Report (1966) Technical Report Series No. 321. World Health Organization, Geneva. 